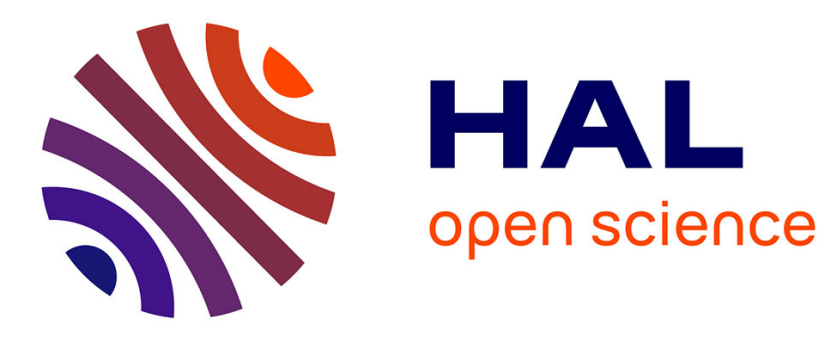

\title{
Sustainable Approach for Tannery Wastewater Treatment: Bioelectricity Generation in Bioelectrochemical Systems
}

\author{
Alae Elabed, Soumya El Abed, Saad Ibnsouda, Benjamin Erable
}

\section{To cite this version:}

Alae Elabed, Soumya El Abed, Saad Ibnsouda, Benjamin Erable. Sustainable Approach for Tannery Wastewater Treatment: Bioelectricity Generation in Bioelectrochemical Systems. Arabian Journal For Science and Engineering, 2019, pp.1-10. 10.1007/s13369-019-04050-y . hal-02284196

\section{HAL Id: hal-02284196 https://hal.science/hal-02284196}

Submitted on 11 Sep 2019

HAL is a multi-disciplinary open access archive for the deposit and dissemination of scientific research documents, whether they are published or not. The documents may come from teaching and research institutions in France or abroad, or from public or private research centers.
L'archive ouverte pluridisciplinaire HAL, est destinée au dépôt et à la diffusion de documents scientifiques de niveau recherche, publiés ou non, émanant des établissements d'enseignement et de recherche français ou étrangers, des laboratoires publics ou privés. 


\section{OATAO \\ Open Archive Toulouse Archive Ouverte}

\section{Open Archive Toulouse Archive Ouverte (OATAO)}

OATAO is an open access repository that collects the work of Toulouse researchers and makes it freely available over the web where possible

This is an author's version published in: http://oatao.univ-toulouse.fr/24212

Official URL: https://doi.org/10.1007/s13369-019-04050-y

\section{To cite this version:}

Elabed, Alae Benjamin $\rightleftharpoons$ Sustainable Approach for Tannery Wastewater Treatment: Bioelectricity Generation in Bioelectrochemical Systems. (2019) Arabian Journal for Science and Engineering. 1-10. ISSN 2193-567X

Any correspondence concerning this service should be sent to the repository administrator: tech-oatao@listes-diff.inp-toulouse.fr 


\title{
Sustainable Approach for Tannery Wastewater Treatment: Bioelectricity Generation in Bioelectrochemical Systems
}

\author{
Alae Elabed ${ }^{1,3} \cdot$ Soumya El Abed ${ }^{2} \cdot$ Saad Ibnsouda ${ }^{2,3} \cdot$ Benjamin Erable $^{1}$
}

\begin{abstract}
Treating tannery wastewater in bioelectrochemical systems (BESs) is considered as an achievable, economical and sustainable process compared to conventional methods. Two experiments with raw and pretreated tannery wastewater were operated separately to elucidate the divergence to form an efficient microbial anode under similar operating conditions [temperature $\left(30 \pm 0.1{ }^{\circ} \mathrm{C}\right)$; acidophilic microenvironment $(\mathrm{pH} 4.5)$, constant potential $-0.2 \mathrm{~V} / \mathrm{ECS}$ ]. In the reactor operated with raw tanneries, no microbial activity was detected due to the toxicity of the tannery effluent. While, the reactor fed by tannery wastewater that sustained electrochemical pretreatment demonstrated the ability of in situ bioelectricity generation along with wastewater treatment. Maximum current density of $11.2 \mathrm{~A} / \mathrm{m}^{2}$ was obtained accompanied with removal of $90 \%, 84 \%$ and $96 \%$, respectively, of chemical oxygen demand, biological oxygen demand (BOD 5 ) and sulfate in addition of total removal of chromium. This study shows the potential approach of electrochemical pretreatment for the efficient tannery wastewater treatment using BESs accompanied with high current recovery.
\end{abstract}

Keywords Microbial fuel cell $\cdot$ Tannery wastewater treatment $\cdot$ Electrochemical pretreatment $\cdot$ Microbial anode

\section{Introduction}

Leather tanning is one of the oldest industries in the world. It is known to be one of the most important industries in Mediterranean countries. Prominent in Morocco, particularly in the city of Fez where tannery industries make up 53\% of the city's employment, $24 \%$ of industrial production and $23 \%$ of added value [1]. However, tanneries are among the industries generating the most hazardous effluents. Acids, chromium salts, tannins, solvents, sulfides, dyes and many other chemical compounds are used in the processing of raw hides and skins to marketable leather. But most of those hazardous compounds are not completely fixed during the skin treatment process and remain in the effluent $[2,3]$. Thus, various treatment technologies have been studied by the researchers

Alae Elabed

alae.elabed@gmail.com

1 Laboratoire de Génie Chimique, Université de Toulouse, CNRS, INP, UPS, Toulouse, France

2 Centre Universitaire Régional d'Interface, Université Sidi Mohamed Ben Abdellah, Fès, Morocco

3 Laboratoire de Biotechnologie Microbienne, Faculté des Sciences et Techniques, Fès, Morocco worldwide to treat this toxic effluent: membrane processes [1], advanced oxidation processes [4], coagulation and flocculation [5], electrochemical treatment [6, 7], aerobic and anaerobic processes [8]. Biological treatments have greatly improved and stabilized when the effluent is first pretreated with a chemical or a physical process. But sulfide contents are often not reduced by these pretreatment steps and are often the cause of serious inhibition of biological treatment of tannery wastewater [9].

Microbial fuel cell (MFC) has been actually described as a clean, economically as well as environmentally sustainable wastewater treatment technology [10, 11]. MFC offers the great advantages of extracting the chemical energy contained in wastewater under anaerobic conditions leading to their treatment and at the same time to the generation of an electrical energy. Thanks to this bioelectrochemical process emerged in early 2000 [12], urban and industrial wastewater are not only considered as constraining wastes that must be absolutely treated but as a free resource that can be today energetically valued. The full commercial application of wastewater treatment by MFCs was discussed by Trapero et al. (2017). They concluded that the implementation of MFC is a promising alternative to the use of classical aerated activated sludge, and it has potential economic benefits 
Table 1 Different wastewater used to form microbial anode

\begin{tabular}{llll}
\hline $\begin{array}{l}\text { Current density } \\
\left(\mathrm{A} / \mathrm{m}^{2}\right)\end{array}$ & Wastewaters & $\begin{array}{l}\text { COD removal } \\
(\%)\end{array}$ & References \\
\hline 0.9 & $\begin{array}{l}\text { Starch } \\
\text { processing } \\
\text { wastewater } \\
\text { Refinery } \\
\text { wastewater }\end{array}$ & 98 & {$[33]$} \\
1.14 & $\begin{array}{l}\text { Brewery } \\
\text { wastewater }\end{array}$ & 86 & {$[34]$} \\
2 & $\begin{array}{c}\text { Chocolate } \\
\text { wastewater }\end{array}$ & 75 & {$[35]$} \\
3 & $\begin{array}{l}\text { Paper industrial } \\
\text { wastewater }\end{array}$ & $65-75$ & {$[36]$} \\
$4-6$ & $\begin{array}{c}\text { Tannery } \\
\text { wastewater }\end{array}$ & 93 & {$[37]$} \\
11.2 & & This work \\
\hline
\end{tabular}

[13]. Starting from 2004, potential applications of MFC in domestic and industrial wastewater treatment and electricity generation have been successfully tested considering various complex organic wastewater, either as fuel or as a source of electroactive bacteria (Table 1).

The effluents of tanneries have a number of advantages, suggesting that they are good candidates to be recycled and valued in MFC.

1. Acidic effluents $(\mathrm{pH} \leq 4)$ : The acidic $\mathrm{pH}$ of wastewater from tanneries is a true asset to the operation of the oxygen reduction cathodes. Indeed, oxygen reduction was no longer limited by $\mathrm{H}^{+}$availability at low $\mathrm{pH}$ [14]. Operating MFC in acidophilic environment is also attractive because it naturally limits the growth of methanogens responsible for the major electrons loss in MFC. Methanogenic bacterial population must be inhibited in order to improve electrons recovery at the bioanode. Various environmental stress conditions such as oxygen stress, low $\mathrm{pH}$ and inhibitor addition (2bromoethanesulfonate) have been already proposed in the literature [15].

2. Complex highly loaded industrial wastewaters: Bacterial endogenous communities living in a complex effluent loaded with heavy metal and sulfur compounds and high organic content make tannery wastewater a suitable source of electroactive bacteria that can acclimate to various environmental stress conditions. The performances of a microbial anode (and more broadly of a MFC) are dependent on the fuel concentration to be oxidized. Several studies have shown that the generated current showed a gradual increase with respect to the increase in COD loading until the limit of 3000-6000 mg COD/L depending on the complexity of the COD $[16,17]$.
Highly efficient bioanodes were obtained with stainless steel foam bioanode $\left(80 \mathrm{~A} / \mathrm{m}^{2}\right)$ [18] and $67 \mathrm{~A} / \mathrm{m}^{2}$ with layered corrugated carbon bioanode [19] in synthetic medium. In contrast, the bioanode designed to treat real wastewater still faces practical barriers such as low current density [20], especially under complex and toxic environment such tannery wastewater [21, 22]. So, further extensive research and developments concerning the formation of efficient bioanodes are urgently required and will help in the treatment of real wastewater and the efficiency of current collection in MFCs for field implementation.

In this paper, the applicability of electrochemical pretreatment of an industrial tannery wastewater to form an efficient microbial anode compared to raw tannery wastewater was investigated. The main reasons for this approach were (1) to investigate the MFC technology on the removal of the organic and other pollutants from the tannery wastewater (2) to develop a method for selecting an electroactive biofilm suitable for oxidation of complex tannery effluents, and (3) to study the effectiveness of combining electrochemical pretreatment + electroactive biofilm for the treatment of tannery wastewater.

\section{Materials and Methods}

\subsection{Wastewater Analysis}

Tannery wastewater $(8 \mathrm{~L})$ was sampled from Fez tanneries (Fez, Morocco). Samples were transported on ice in polyethylene containers, upon arrival in laboratory. The samples were stored at $4{ }^{\circ} \mathrm{C}$. All physicochemical proprieties were analyzed according to standard methods. COD, $\mathrm{BOD}_{5}$ and sulfate were measured using a photometric cuvette test [LCK514 kit (COD measurement 100-2000 $\mathrm{mgO}_{2} / \mathrm{L}$ ), LCK555 kit (BOD measurement $4-1650 \mathrm{mgO}_{2} / \mathrm{L}$ ) and LCK353 kit ( $\mathrm{SO}_{4}$ measurement $\left.\left.150-900 \mathrm{mgSO}_{4} / \mathrm{L}\right)\right]$.

Total chromium was determined by inductively coupled plasma atomic emission spectroscopy (ICP-AES). Each test was performed in triplicate, and the mean values were given with standard deviations.

Statistical analyses were carried out using XLSTAT 7. Pair-wise Student's $t$ tests were used to check if the value of each considered parameter was significantly different between the two treatment steps.

\subsection{Electrochemical Experiments}

All the experiments were conducted at $30{ }^{\circ} \mathrm{C}$ and were operated in three electrode bioreactors, each equipped with a $2 \mathrm{~cm}^{2}$ projected surface area working electrode connected electrically via a thin platinum wire, a saturated calomel reference electrode (SCE, $+0.24 \mathrm{~V}$ vs. SHE) and a $6-\mathrm{cm}^{2}-$ 
platinum-grid auxiliary electrode. All the working electrodes were polarized under at $-0.2 \mathrm{~V} / \mathrm{SCE}$ using a multi-channel potentiostat (Biologic VSP2). The polarization was periodically suspended to perform cyclic voltammetries at $1 \mathrm{mV} / \mathrm{s}$ in the potential range of $0.3 \mathrm{~V} / \mathrm{SCE}$ and $-0.5 \mathrm{~V} / \mathrm{SCE}$.

\subsubsection{Wastewater Electrochemical Pretreatment}

Electrochemical pretreatment was operated in a reactor described above fed by raw tannery wastewater and equipped with 254SMO stainless steel as working electrodes, without any supplementation of nutriments or substrates.

\subsubsection{Microbial anode Formation}

The experiments were studied in parallel with raw tannery wastewater and pretreated tannery wastewater. Carbon felt anode was used to form electroactive biofilm tannery wastewater without any supplementation of nutriment, except $20 \mathrm{mM}$ of glucose.

\subsection{Scanning Electron Microscopy (SEM) and Energy-Dispersive X-ray Spectrometry (EDX) Analysis}

Microbial biofilms developed on working electrodes (bioanodes) were fixed in phosphate buffer $(400 \mathrm{mM}, \mathrm{pH}=7.4)$ with $4 \%$ glutaraldehyde. They were rinsed in phosphate buffer containing saccharose $(0.4 \mathrm{M})$ and dehydrated by immersion in increasing concentrations of acetone $(50 \%$, $70 \%, 100 \%)$, then in acetone and hexamethyldisilazane (50:50), and in 100\% hexamethyldisilazane (HMDS). The last batch of HMDS was dried until complete evaporation.

The morphologies of the electrode surface were investigated by scanning electron microscopy (SEM, Jeol). The composition of the deposits was obtained using combined energy-dispersive X-ray spectroscopy (EDX).

\subsection{Epifluorescence Microscopy}

The electrodes were extracted from the bioreactors and washed carefully with sterile physiological water to remove all soluble and solid materials except the attached biofilms. Bioelectrodes were stained with $0.03 \%$ acridine orange (A6014, Sigma) for $10 \mathrm{~min}$, rinsed with sterile physiological water and then left to dry at room temperature. The biofilms were imaged with a Carl Zeiss Axio Imager-M2 microscope equipped for epifluorescence with an HXP $200 \mathrm{C}$ light source and the Zeiss 09 filter (excitor HP450e 490, reflector FT 10, barrier filter LP520). Images were acquired with a digital camera (Zeiss AxioCamMRm) every $0.5 \mu \mathrm{m}$ along the Zaxis, and the set of images was processed with the Zen ${ }^{\circledR}$ software.
Table 2 Characteristic of tannery wastewater before and after treatment

\begin{tabular}{llcl}
\hline & Effluent $(\mathrm{mg} / \mathrm{L})$ & $\begin{array}{l}\text { After } \\
\text { pretreatment } \\
(\mathrm{mg} / \mathrm{L})\end{array}$ & $\begin{array}{l}\text { After bioelectro- } \\
\text { chemical } \\
\text { treatment } \\
(\mathrm{mg} / \mathrm{L})\end{array}$ \\
\hline DCO & $2787 \pm 262$ & $1580 \pm 103$ & $258 \pm 34$ \\
& & $(0.0028)$ & $(0.0013)$ \\
DBO & $508 \pm 86$ & $488 \pm 68$ & $84 \pm 6.3$ \\
& & $(0.0970)$ & $(0.0059)$ \\
Chromium & $596 \pm 35$ & $237 \pm 26$ & $<0.01(0.0005)$ \\
& & $(0.0001)$ & \\
pH & 4.01 & 4.5 & 7.24 \\
Sulfate & $2848 \pm 382$ & $184 \pm 12$ & $28 \pm 3.2$ \\
& & $(0.0031)$ & $(0.0029)$ \\
\hline
\end{tabular}

Mean \pm standard deviation ( $p$ value)

\section{Results and Discussion}

\subsection{Tannery Wastewater Specific Characteristics}

As reported in the literature, the characteristics of tannery wastewater change considerably from tannery to tannery depending upon the size of the tannery, chemicals used for a specific process, amount of water used and type of final product produced by a tannery. On the basis of several previous works, tannery wastewater was generally characterized by COD, BOD, sulfate, heavy metal mainly chromium and sodium [23]. It should be noted that different heavy metals (As, $\mathrm{Co}, \mathrm{Al}, \mathrm{Zn}$, etc.) have measured. However, their concentrations were below the detection limit.

The measured value for $\mathrm{pH}, \mathrm{COD}, \mathrm{BOD}$, chromium and sulfate concentrations of tannery wastewater and standard deviations is given in Table 2.

The $\mathrm{pH}$ value of industrial tannery wastewater was above 4.01. The COD and $\mathrm{BOD}_{5}$ values, $2787 \pm 262 \mathrm{mg} / \mathrm{L}$ and $508 \pm 86 \mathrm{mg} / \mathrm{L}$, respectively, are considerably high. The average $\mathrm{BOD}_{5} / \mathrm{COD}$ ratio of 0.2 indicated the low biodegradability of tannery wastewater. High chromium and sulfate contents were observed in the raw tannery wastewater with a mean value of $596 \pm 35 \mathrm{mg} / \mathrm{L}$ and $2848 \pm 382 \mathrm{mg} / \mathrm{L}$, respectively, which greatly impact bacterial viability [24].

\subsection{Effect of Electrode Material in Pretreatment of Raw Tannery Wastewater}

The low biodegradability of tannery wastewater requires a pretreatment to make it biodegradable. Thus, the experiments were initiated to determine whether electrode material was suitable to pretreat tannery wastewater. Three electrode materials (254SMO stainless steel, carbon felt, graphite) have been compared as working electrodes. Each electrode material was polarized for 30 days at $-0.2 \mathrm{~V}$ with respect to a 
saturated calomel reference electrode (SCE, $0.245 \mathrm{~V} / \mathrm{SHE}$ ) $[25,26]$.

The experiments with graphite and felt carbon electrodes were unsuccessful to electrodeposit any substance. The wastewater analyses confirm these results, and the COD, sulfate and chromium concentrations in the tannery wastewater were unchanged during 30 days (data not presented). But in the case of 254SMO stainless steel was used, positive current about few hundred $\mathrm{mA} / \mathrm{m}^{2}$ was detected from the start of the chronoamperometry, suggesting, without any doubt, the abiotic electrochemical catalysis of an electrochemical reaction directly on surface electrode material. In parallel, COD, sulfate and chromium removal were observed (Table 2) and accompanied by a deposited layer on surface material.

Chromium and sulfate are usually described for affecting biological treatment by microbial biomass poisoning [8]. From this observation, the new objective was to electrochemically pretreat tannery wastewater for removing toxic contaminant of chromium and sulfate present in wastewater by electrodepositing on 254SMO stainless steel anode. After tannery wastewater was pretreated, raw tannery wastewater and pretreated tannery wastewater were compared to develop microbial anodes.

\subsection{Electrochemical Pretreatment of Tannery Wastewater (254SMO Stainless Steel)}

Based on the results obtained in Sect. 2.2, raw tannery wastewater was pretreated in electrochemical reactors (600 ml) using 254 SMO stainless steel working electrode polarized at $-0.2 \mathrm{~V} / \mathrm{SCE}$. Soluble substances present in tannery wastewater reacted spontaneously on the surface 254 SMO stainless steel polarized electrode. Figure 1 depicts the evolution of the current density according time. A stationary current of $1 \mathrm{~A} / \mathrm{m}^{2}$ was obtained as soon the stainless steel electrode has been polarized (chronoamperometry at $-0.2 \mathrm{~V} / \mathrm{SCE}$ ). The current decreased over time as reacting aqueous substance was removed from the tannery effluent. After 4 days of the operation, the current density was stabilized around $0.5 \mathrm{~A} / \mathrm{m}^{2}$ along 5 days. One of two hypotheses can explain this limitation electron transfer: (1) deactivation of the electrode reactivity due to the deposition of abiotic redox substance or other wastewater reactive constituents (2) the concentration of the substance oxidized on the anode was removed. To check these hypotheses, the 254SMO stainless steel anode was changed by another clean electrode. Under the same condition, the initial current density increased with the clean stainless steel anode, and consequently the substance oxidation rate increases (Fig. 1).

The current density recorded was $2 \mathrm{~A} / \mathrm{m}^{2}$ decreasing over time until became nil. This means that the soluble reacting substances were removed totally from the tannery effluent. The composition of the deposits was obtained using energy- dispersive X-ray spectroscopy (EDX). Table 3 shows the presence of many elemental on the electrode surface; mainly sulfur. The chemicals removed by electrochemical pretreatment passivate the electrode surface and subsequently control the process.

Moreover, it is known that the reduction in the heavy metal contaminants as a solid metal deposit on particles can either be safely discarded as such or further processed to recover particular metals. It is assumed that these are trapped wastewater particulates. However, sulfur deposits on the anode described in the literature as an inhibitor of electroactive biofilms formation as reported by [27]. To investigate this, the two electrode surface coverage after the operation was evaluated by SEM. The SEM images (Fig. 2) show the absence of biofilm and the presence of deposited layer in the electrode surface. This implies that the electrochemical oxidation reaction generated the deposition of sulfur and other chemical constituents/particulate materials present in the tannery wastewater leading to their removal from wastewater. The COD, BOD, chromium and sulfate removal after the pretreatment of tannery wastewater were, in average, that of $1580 \pm 103 \%, 488 \pm 68 \%, 237 \pm 68$ and $184 \pm 12$, respectively.

These results are within of those reported in the current literature for the treatment of paper mill wastewater with MFCs. The hydrogen sulfide could be effectively removed by electrochemical oxidation with concomitant electricity generation according reaction Eq. 1 [28].

Verma et al. [29] demonstrated the feasibility to remove $68 \%$ of chromium in acidophilic condition $\mathrm{pH}(\mathrm{pH}=5)$ due to the hydrogen sulfide which reacts with heavy metal ions to form insoluble metal sulfide; this can be explained by the removal of $60 \%$ chromium $(\mathrm{pH}=4.5)$.

$$
\mathrm{H}_{2} \mathrm{~S} \rightarrow \mathrm{S}(s)+2 \mathrm{e}^{-}+2 \mathrm{H}^{+}\left(\mathrm{pH}=4 ; E^{\circ}=-370 \mathrm{mV} / \mathrm{ECS}\right) .
$$

\subsection{Comparison of Raw and Pretreated Tannery Wastewater for Bioanodes Formation}

\subsubsection{Chronoamperometries Analysis}

Two microbial anodes were developed in parallel with carbon felt electrode material in two different reactors, under constant polarization at $-0.2 \mathrm{~V} / \mathrm{SCE}$, with successive additions of $20 \mathrm{mM}$ glucose. One reactor was fed with a raw tannery wastewater, the other with a pretreated tannery wastewater.

The reactor fed by raw tannery wastewater could not produce any current, and no electro-microbial activity was detected (Fig. 3). The physicochemical characteristics of the raw wastewater remained unchanged during the whole experiment. While, the current intensities started to increase exponentially from the beginning in the bioreactor fed by 
Fig. 1 Current density provided by a 254 SMO stainless steel anode polarized at $0.2 \mathrm{~V} / \mathrm{SCE}$ in raw tannery wastewater

Table 3 EDX analysis of 254SMO stainless steel anode

Fig. 2 SEM analysis of stainless steel anode. a First stainless steel electrode. b Second stainless steel electrode

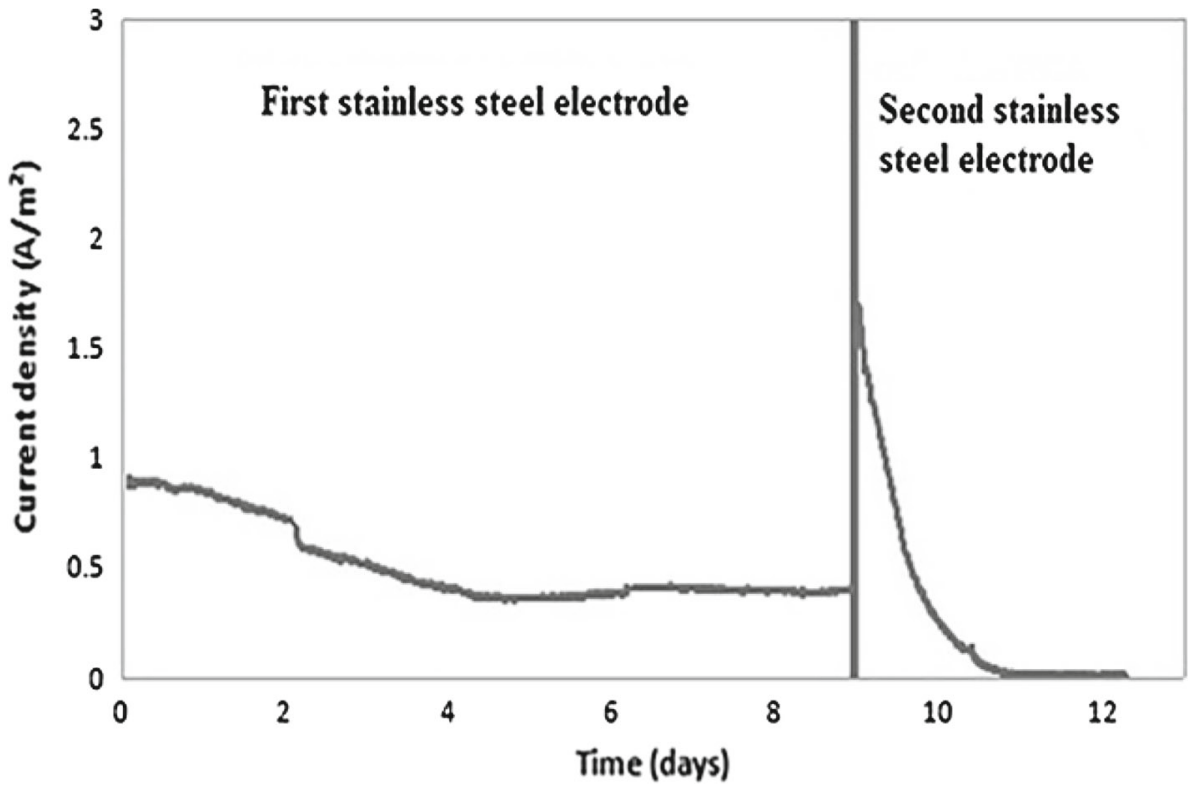

\begin{tabular}{lllllllllllllll}
\hline Elements & $\mathrm{C}$ & $\mathrm{Cr}$ & $\mathrm{Fe}$ & $\mathrm{Mo}$ & $\mathrm{N}$ & $\mathrm{S}$ & $\mathrm{Ni}$ & $\mathrm{Al}$ & $\mathrm{Na}$ & $\mathrm{Ca}$ & $\mathrm{Si}$ & $\mathrm{O}$ & $\mathrm{Cl}$ & $\mathrm{F}$ \\
\hline Stainless steel & - & 18.2 & 56.9 & 6.1 & 0.1 & - & 17.9 & - & - & - & 0.8 & - & - & - \\
Polarized stainless steel 1 & 30 & 3.3 & 10.7 & - & - & 40.6 & 1.4 & 1.1 & 0.6 & 0.4 & 1 & - & - & - \\
Polarized stainless steel 2 & 38.5 & 4.9 & 4.1 & - & 8.8 & 21.9 & 1.9 & 0.4 & 3.6 & 1.2 & 0.2 & 13.0 & 0.8 & 0.8 \\
\hline
\end{tabular}
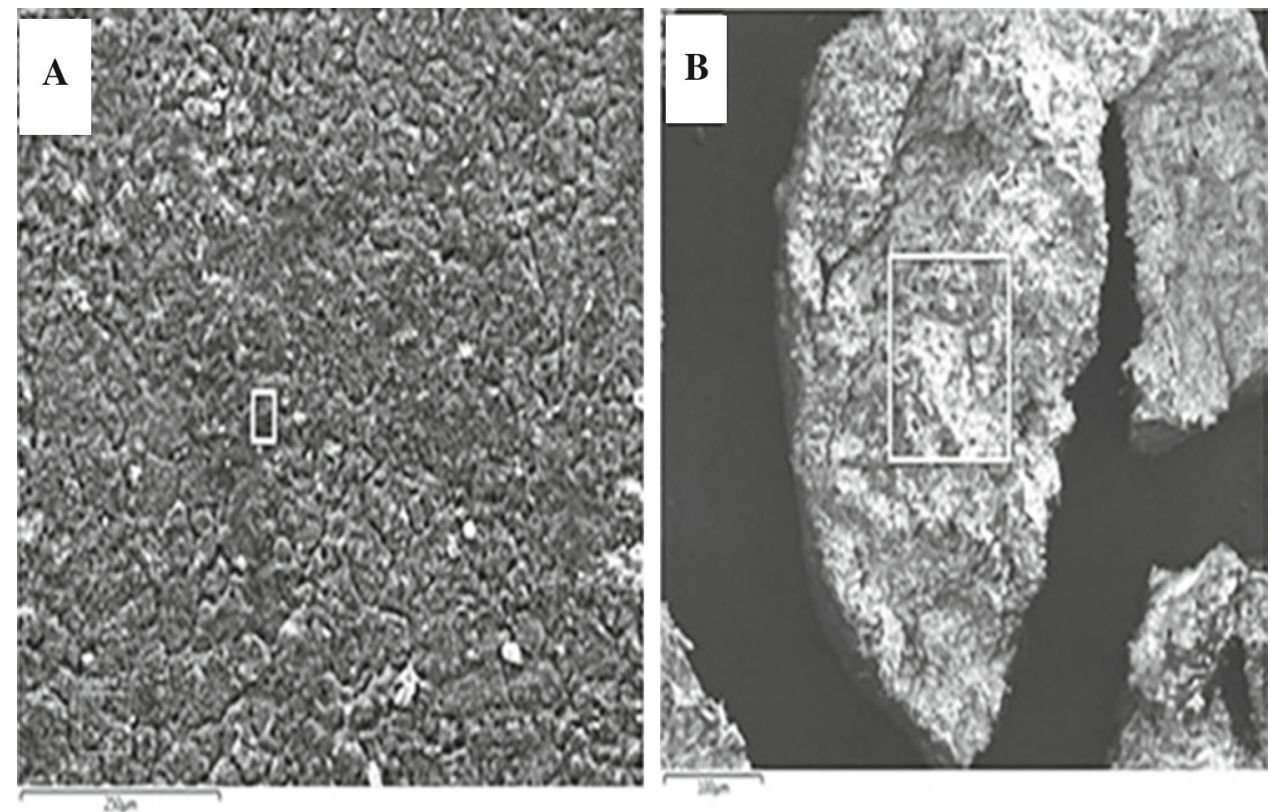

pretreated tannery wastewater. In the first and the third day, we added $20 \mathrm{mM}$ of glucose to help electrogenic community to develop and colonize the carbon felt anode, the drops of the current density are a result of glucose consumption. Addition of glucose leads to an increase in current. The maximum current density of $11.2 \mathrm{~A} / \mathrm{m}^{2}$ was obtained at day 6 (Fig. 3), and the current dropped off because of complete utilization of the carbon sources. As commonly reported, the current was generated by the biofilm-catalyzed glucose oxidation:

$\mathrm{C}_{6} \mathrm{H}_{12} \mathrm{O}_{6}+6 \mathrm{H}_{2} \mathrm{O} \rightarrow 6 \mathrm{CO}_{2}+24 \mathrm{H}^{+}+24 \mathrm{e}^{-}$

The overall COD, BOD, sulfate and chromium removal of pretreated tannery wastewater reach $90 \%, 84 \%, 99 \%$ and 
Fig. 3 Current density obtained by a carbon felt anode polarized at $0.2 \mathrm{~V} / \mathrm{SCE}$ in pretreated tannery wastewater (dark gray) and in raw tannery wastewater (light gray)

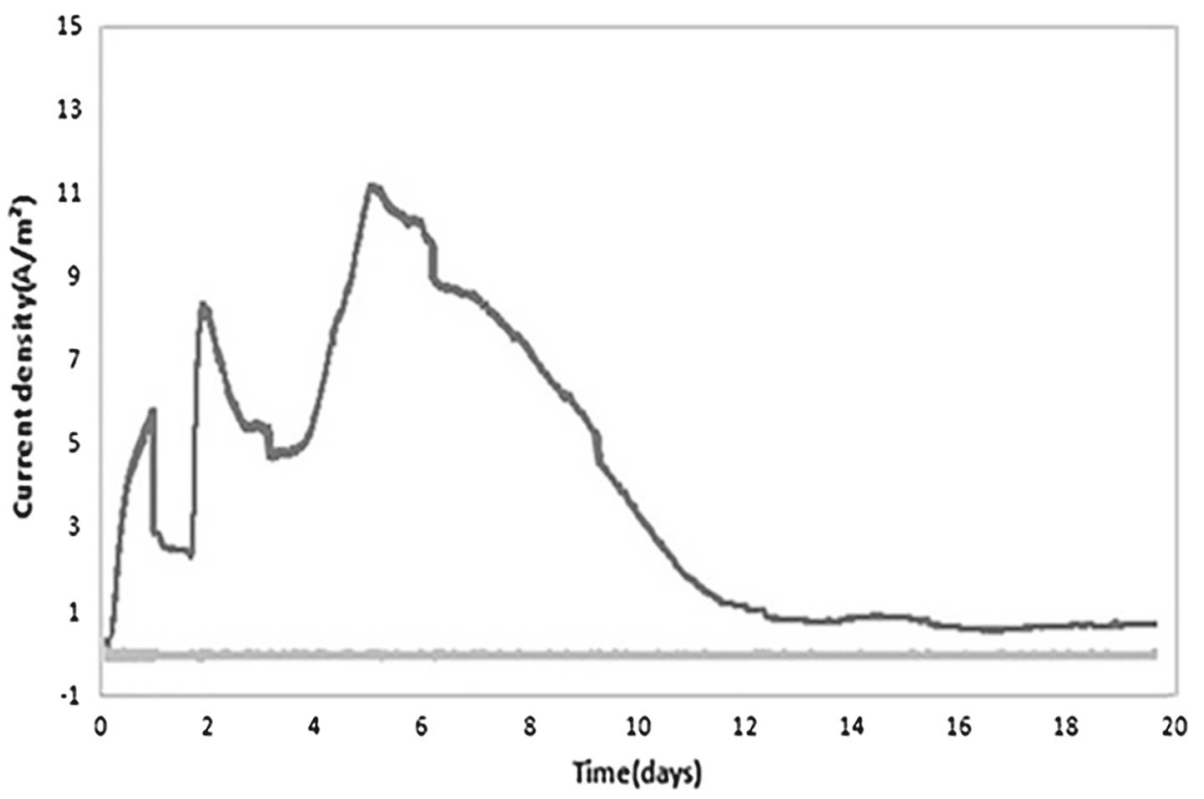

$100 \%$, respectively, at the end of the chronoamperometry (after 20 days of operation). Pair-wise Student's $t$ tests showed that the mean removal of each considered parameter decreased significantly at each step of the treatment process ( $p$ value $<0.05)$.

To the best of our knowledge, the present study seems to pioneer the assessment of the highest current densities reported for microbial anodes using wastewater as inoculums (Table 1) which show interest to use tannery wastewater as a source of electroactive biofilm.

Mathuriya [21] inoculated tannery wastewater in MFC with three bacterial isolates, mixed consortia of isolates and activated sludge inoculum using plain carbon paper anode at neutral $\mathrm{pH}$. The higher value of current generated $2.88 \mathrm{~A} / \mathrm{m}^{2}$ and $2.25 \mathrm{~A} / \mathrm{m}^{2}$ was obtained with mixed microbial consortia and activated sludge inoculums, respectively [21]. The value of $11.2 \mathrm{~A} / \mathrm{m}^{2}$ obtained in our work was more than three times that provided mixed microbial consortia and five times with active sludge inoculums.

It is noted that after pretreatment of tannery wastewater the $\mathrm{pH}$ was 4.5 . Operating anodic chamber at acidophilic conditions ( $\mathrm{pH} 4.5$ ) helped to sustain the activity of acidogenic bacteria and at the same time inhibiting methanogenic bacterial.

These findings were further corroborated with the work of [30]. During chemical wastewater treatment employing anaerobic mixed consortia as anodic biocatalyst at room temperature $\left(29 \pm 2{ }^{\circ} \mathrm{C}\right)$ in $\mathrm{MFC}$, the higher current density and coulombic efficiency were observed at acidophilic conditions ( $\mathrm{pH}$ 6) compared to neutral and alkaline conditions ( $\mathrm{pH} \mathrm{8).}$

In the other work, the coulombic efficiency was increased from 40 to $70 \%$ by adding 2-bromoethanesulfonate as an inhibitor of methanogenesis activity [31].

\subsubsection{Cyclic Voltammetry Analysis}

Cyclic voltammetry has regularly been exploited to study and to characterize the electron transfer interactions between microbial biofilms and material anodes. Applying cyclic voltammetry at different phases of microbial growth and metabolic activity can be providing important information on the anodic electron transfer processes. Catalytic cyclic voltammetries were recorded in turnover condition at days 0.3 and 6 (Fig. 4).

The zero current potential, determined at the intersection of CV curves with the axe of potentials $(x)$, was estimated at $E=-390 \mathrm{mV} / \mathrm{ECS}(\mathrm{pH}=4.5)$. This value of potential is really closed to the redox potential of the couple acetate $/ \mathrm{CO}_{2}$ at $\mathrm{pH}$ 4.5. The glucose (and/or natural COD of wastewater) oxidation probably passed through acetate intermediates as already evidenced by Huang and Logan (2008). In their work, the hydrolysis and fermentation of the particulate substance (COD, glucose) present in paper recycling wastewater released different product intermediates, and the acetate was the dominant intermediate [32]. Other authors demonstrated in anaerobic condition glucose can be fermented to acetate according to Eqs. 3, 4 and 5:

Glucose $\rightarrow 2$ acetate +3 Butyrate $+8 \mathrm{CO}_{2}+\mathrm{H}_{2}$

Glucose $\rightarrow$ acetate + propanoic acid $+\mathrm{CO}_{2}+\mathrm{H}_{2}$

Glucose $+3 \mathrm{ADP}+3 \mathrm{Pi} \rightarrow 3$ acetate +3 ATP

Figure 4 shows that catalytic activity of electron transfer increases over time (from 0 to 6 days). After 6 days of operation, the rate of electron transfer rose rapidly at a poten- 
Fig. 4 Cyclic voltammetries $(1 \mathrm{mV} / \mathrm{s})$ obtained by a carbon felt anode polarized at $0.2 \mathrm{~V} / \mathrm{SCE}$ after 1,3 or 6 days: In pretreated tannery wastewater (a) and raw tannery wastewater (b). The CVs were performed 10 min after the constant polarization was stopped
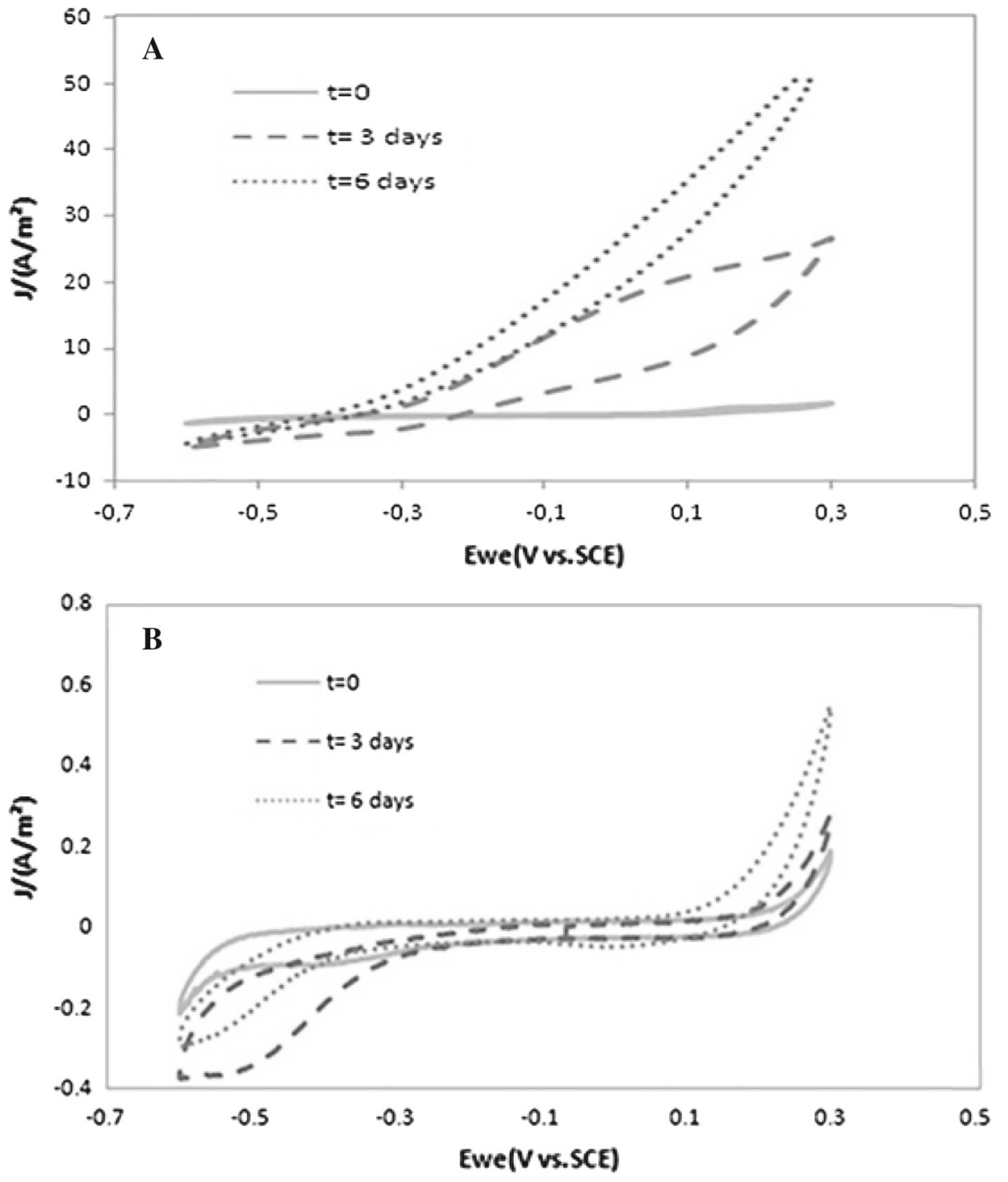

tial higher than $-0.4 \mathrm{~V}$, reaching a limiting current above a potential of 0.1 indicated continuous regeneration of the entire series of proteins catalyzing electrons transfer from the substrate to the electrode. At $0.1 \mathrm{~V} / \mathrm{ECS}$, the behavior current potential had more efficiency. The CV curves showed that it could provide up to $40 \mathrm{~A} / \mathrm{m}^{2}$ (Fig. 4a). However, carbon felt electrode introduced into raw tannery wastewater did not detect any faradic current during time (Fig. 4b).

\subsubsection{Biofilm Structure}

Felt carbon anodes immerged in raw and pretreated tannery wastewater for 15 days were imaged by scanning electron microscopy (SEM) and epifluorescence microscopy. Scanning electron microscopy confirms the absence of biofilm, and it shows scattered deposited particulate materials on the surface of felt carbon anode immerged in raw tannery wastewater (Fig. 5).

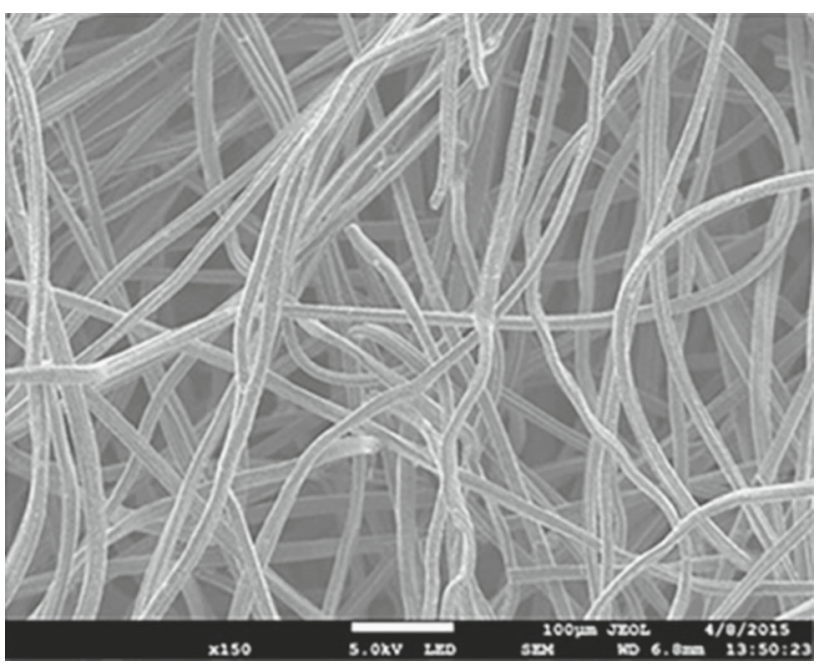

Fig. 5 SEM image of carbon felt anode immerged in raw tannery wastewater 
Table 4 EDX analysis of carbon felt immerged in raw tannery wastewater

\begin{tabular}{lllllllllll}
\hline Elements & $\mathrm{C}$ & $\mathrm{Cr}$ & $\mathrm{K}$ & $\mathrm{S}$ & $\mathrm{Al}$ & $\mathrm{Na}$ & $\mathrm{P}$ & $\mathrm{Si}$ & $\mathrm{O}$ & $\mathrm{Ca}$ \\
\hline Carbon felt & 96 & - & - & - & - & - & - & - & 4 & - \\
Polarized carbon felt & 62.9 & 0.4 & 0.1 & 7.2 & 4.9 & 0.9 & 0.6 & 1 & 15.5 & 0.2 \\
\hline
\end{tabular}
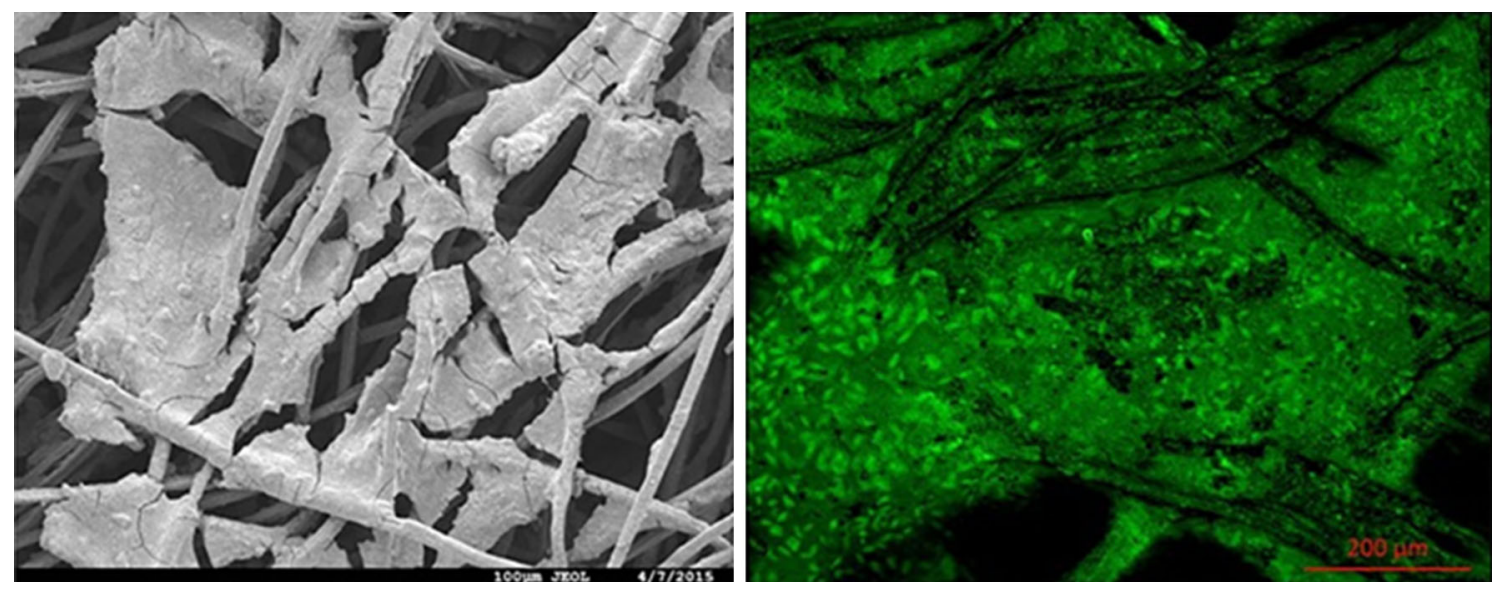

Fig. 6 SEM and epifluorescence images of carbon felt anode immerged in pretreated tannery wastewater

EDX analysis showed that the main atomic composition of particulate materials deposited is sulfur compound (Table 4). So, lack microbial colonization in this anode can be explained by the presence of toxic and excess nonbiodegradable chemicals, preservatives and other inorganic chemicals predominantly sulfur compound, which affect the biofilm formation.

The carbon felt anode immerged in pretreated tannery wastewater showed an extended biofilm covering all electrode surfaces (Fig. 6). The use of epifluorescence microscopy in conjunction with SEM examination confirms the existence of biofilm, and the biofilm coverage ratio was evaluated as $34 \%$ of the total amount of the first $200 \mu \mathrm{m}$ thickness of the carbon felt.

\subsection{Practical Implementation and Future Research}

Microbial fuel cells (MFCs) have been researched and are now recognized as an innovative technology that has certain advantages especially in the field of wastewater treatment. However, the selection of high performing bioanode to treat real wastewater has to be one of the main challenges standing in the way of the MFC development [20]. High current density was obtained in synthetic medium. While, the current densities of bioanodes designed to treat the real raw effluent remain modest (Table 1). The high current density obtained in this study compared with the literature suggests that tannery wastewater loaded with heavy metals and sulfur compounds and high organic content could be a suitable source of electroactive bacteria that can acclimate to various environmental stress conditions. If used, this source could help fill the large gap between real raw wastewater and synthetic medium and thus contribute to overcoming the practical barriers such as low current density. Further research should also pay attention to new materials (anode/cathode) in order to make electron transfer and wastewater treatment more effective. On the other hand, the energy recovery generally decreases with increasing scale MFCs and under continuous operating mode the efforts to overcome these challenges are still ebullient.

\section{Conclusion}

Application of electrochemical pretreatment of tannery wastewater was studied as a strategy to form an efficient microbial anode in BES and was compared with the raw tannery wastewater at acidophilic condition. Raw tannery wastewater could not form a microbial anode due to sulfate inhibition. On the contrary, bioelectrochemical analysis showed higher catalytic current resulting in effective electrons transfer efficiency after electrochemical pretreatment of tannery wastewater. The high degradation of the organic and inorganic matter in BES could be an alternative tannery wastewater treatment unit in addition to renewable energy generation.

Acknowledgements This work was supported by "Volubilis" project (ANR-10-BTBR- 02) and PPR/2015/14 project. The authors thank Marie-Line de Solan (LGC) for her help with the SEM images. We also kindly thank M. Mohammed Moubtassime for his help in correcting the English version of the manuscript. 


\section{References}

1. Suthanthararajan, R.; Ravindranath, E.; Chitra, K.; Umamaheswari, B.; Ramesh, T.; Rajamani, S.: Membrane application for recovery and reuse of water from treated tannery wastewater. Desalination 164, 151-156 (2004). https://doi.org/10.1016/S00119164(04)00174-2

2. Di Iaconi, C.; Lopez, A.; Ramadori, R.; Di Pinto, A.C.; Passino, R.: Combined chemical and biological degradation of tannery wastewater by a periodic submerged filter (SBBR). Water Res. 36, 2205-2214 (2002). https://doi.org/10.1016/s00431354(01)00445-6

3. Schrank, S.G.; Bieling, U.; José, H.J.; Moreira, R.F.P.M.; Schröder, H.F.: Generation of endocrine disruptor compounds during ozone treatment of tannery wastewater confirmed by biological effect analysis and substance specific analysis. Water Sci. Technol. 59, 31-38 (2009). https://doi.org/10.2166/wst.2009.762

4. Sauer, T.P.; Casaril, L.; Oberziner, A.L.B.; José, H.J.; Moreira, R.D.F.P.M.: Advanced oxidation processes applied to tannery wastewater containing Direct Black 38-Elimination and degradation kinetics. J. Hazard. Mater. 135, 274-279 (2006). https://doi. org/10.1016/j.jhazmat.2005.11.063

5. Haydar, S.; Aziz, J.A.: Coagulation-flocculation studies of tannery wastewater using combination of alum with cationic and anionic polymers. J. Hazard. Mater. 168, 1035-1040 (2009). https://doi. org/10.1016/j.jhazmat.2009.02.140

6. Costa, C.R.; Botta, C.M.R.; Espindola, E.L.G.; Olivi, P.: Electrochemical treatment of tannery wastewater using DSA electrodes. J. Hazard. Mater. 153, 616-627 (2008). https://doi.org/10.1016/j. jhazmat.2007.09.005

7. Szpyrkowicz, L.; Kaul, S.N.; Neti, R.N.; Satyanarayan, S.: Influence of anode material on electrochemical oxidation for the treatment of tannery wastewater. Water Res. 39, 1601-1613 (2005). https://doi.org/10.1016/j.watres.2005.01.016

8. Goswami, S.; Mazumder, D.: Treatment of chrome tannery wastewater by biological process: a mini review. Int. J. Environ. Chem. Ecol. Geol. Geophys. Eng. 7, 798-804 (2013)

9. Durai, G.; Rajasimman, M.: Biological treatment of tannery wastewater: a review. J. Environ. Sci. Technol. 4, 1-17 (2011)

10. Sleutels, T.H.J.A.; TerHeijne, A.; Buisman, C.J.N.; Hamelers, H.V.M.: Bioelectrochemical systems: an outlook for practical applications. Chemsuschem 5, 1012-1019 (2012). https://doi.org/ $10.1002 /$ cssc. 201100732

11. Ezziat, L.; Elabed, A.; Ibnsouda, S.; El Abed, S.: Challenges of microbial fuel cell architecture on heavy metal recovery and removal from wastewater. Front. Energy Res. 7, 1-13 (2019). https://doi.org/10.3389/fenrg.2019.00001

12. Liu, H.; Ramnarayanan, R.; Logan, B.E.: Production of electricity during wastewater treatment using a single chamber microbial fuel cell. Environ. Sci. Technol. 38, 2281-2285 (2004). https://doi.org/ 10.1021/es034923g

13. Trapero, J.R.; Horcajada, L.; Linares, J.J.; Lobato, J.: Is microbial fuel cell technology ready? An economic answer towards industrial commercialization. Appl. Energy 185, 698-707 (2017). https://doi. org/10.1016/j.apenergy.2016.10.109

14. Erable, B.; Bergel, A.: First air-tolerant effective stainless steel microbial anode obtained from a natural marine biofilm. Bioresour. Technol. 100, 3302-3307 (2009). https://doi.org/10.1016/j. biortech.2009.02.025

15. Chae, K.J.; Choi, M.J.; Kim, K.Y.; Ajayi, F.F.; Park, W.; Kim, C.W.; Kim, I.S.: Methanogenesis control by employing various environmental stress conditions in two-chambered microbial fuel cells. Bioresour. Technol. 101, 5350-5357 (2010). https://doi.org/ 10.1016/j.biortech.2010.02.035
16. Anupama, P.; Hampannavar, U.: Microbial fuel cell an alternative for COD removal of distillery wastewater. J. Res. Biol. 1, 419-423 (2011)

17. Mohanakrishna, G.; Mohan, S.V.; Sarma, P.N.: Bioelectrochemical treatment of distillery wastewater in microbial fuel cell facilitating decolorization and desalination along with power generation. J. Hazard. Mater. 177, 487-494 (2010). https:// doi.org/10.1016/j.jhazmat.2009.12.059

18. Ketep, S.F.; Bergel, A.; Calmet, A.; Erable, B.: Stainless steel foam increases the current produced by microbial bioanodes in bioelectrochemical systems. Energy Environ. Sci. 7, 1633 (2014). https:// doi.org/10.1039/c3ee44114h

19. Baudler, A.; Riedl, S.; Schroder, U.: Long-term performance of primary and secondary electroactive biofilms using layered corrugated carbon electrodes. Front. Energy Res. 2, 1-6 (2014). https:// doi.org/10.3389/fenrg.2014.00030

20. Blanchet, E.; Desmond, E.; Erable, B.; Bridier, A.; Bouchez, T.; Bergel, A.: Comparison of synthetic medium and wastewater used as dilution medium to design scalable microbial anodes: application to food waste treatment. Bioresour. Technol. 185, 106-115 (2015). https://doi.org/10.1016/j.biortech.2015.02.097

21. Mathuriya, A.S.: Enhanced tannery wastewater treatment and electricity generation in microbial fuel cell by bacterial strains isolated from tannery waste. Environ. Eng. Manag. J. 13, 2945-2954 (2014)

22. Sawasdee, V.; Pisutpaisal, N.: Simultaneous pollution treatment and electricity generation of tannery wastewater in air-cathode single chamber MFC. Int. J. Hydrogen Energy 41, 15632-15637 (2016). https://doi.org/10.1016/j.ijhydene.2016.04.179

23. Chowdhury, M.; Mostafa, M.G.; Biswas, T.K.; Saha, A.K.: Treatment of leather industrial effluents by filtration and coagulation processes. Water Resour. Ind. 3, 11-22 (2013). https://doi.org/10. 1016/j.wri.2013.05.002

24. Wiemann, M.; Schenk, H.; Hegemann, W.; Universita, T.: Anaerobic treatment of tannery wastewater with simultaneous sulphide elimination. Water Res. 32, 774-780 (1998)

25. Ketep, S.F.; Bergel, A.; Bertrand, M.; Achouak, W.; Fourest, E.: Lowering the applied potential during successive scratching/reinoculation improves the performance of microbial anodes for microbial fuel cells. Bioresour. Technol. 127, 448-455 (2013). https://doi.org/10.1016/j.biortech.2012.09.008

26. Pocaznoi, D.; Erable, B.; Delia, M.-L.; Bergel, A.: Ultra microelectrodes increase the current density provided by electroactive biofilms by improving their electron transport ability. Energy Environ. Sci. 5, 5287 (2012). https://doi.org/10.1039/c1ee01469b

27. Zhao, F.; Rahunen, N.; Varcoe, J.R.; Chandra, A.; Avignone-Rossa, C.; Thumser, A.E.; Slade, R.C.T.: Activated carbon cloth as anode for sulfate removal in a microbial fuel cell. Environ. Sci. Technol. 42, 4971-4976 (2008). https://doi.org/10.1021/es8003766

28. Keller, R.G.; Rabaey, K.: Role of Sulfur during Acetate Oxidation in Biological Anodes. 43, 3839-3845 (2009)

29. Verma, A.; Dua, R.; Singh, A.; Bishnoi, N.R.: Biogenic sulfides for sequestration of $\mathrm{Cr}(\mathrm{VI})$, COD and sulfate from synthetic wastewater. Water Sci. 29, 19-25 (2015). https://doi.org/10.1016/j.wsj. 2015.03.001

30. Raghavulu, S.V.; Mohan, S.V.; Goud, R.K.; Sarma, P.N.: Effect of anodic $\mathrm{pH}$ microenvironment on microbial fuel cell (MFC) performance in concurrence with aerated and ferricyanide catholytes. Electrochem. Commun. 11, 371-375 (2009). https://doi.org/10. 1016/j.elecom.2008.11.038

31. Kim, J.R.; Min, B.; Logan, B.E.: Evaluation of procedures to acclimate a microbial fuel cell for electricity production. Appl. Microbiol. Biotechnol. 68, 23-30 (2005). https://doi.org/10.1007/ s00253-004-1845-6

32. Huang, L.; Logan, B.E.: Electricity generation and treatment of paper recycling wastewater using a microbial fuel cell. Appl. 
Microbiol. Biotechnol. 80, 349-355 (2008). https://doi.org/10. 1007/s00253-008-1546-7

33. Lu, N.; Zhou, S.; Zhuang, L.; Zhang, J.; Ni, J.: Electricity generation from starch processing wastewater using microbial fuel cell technology. Biochem. Eng. J. 43, 246-251 (2009). https://doi.org/ 10.1016/j.bej.2008.10.005

34. Zhang, F.; Ahn, Y.; Logan, B.E.: Treating refinery wastewaters in microbial fuel cells using separator electrode assembly or spaced electrode configurations. Bioresour. Technol. 152, 46-52 (2014). https://doi.org/10.1016/j.biortech.2013.10.103

35. Feng, Y.; Wang, X.; Logan, B.E.; Lee, H.: Brewery wastewater treatment using air-cathode microbial fuel cells. Appl. Microbiol. Biotechnol. 78, 873-880 (2008). https://doi.org/10.1007/s00253008-1360-2
36. Patil, S.A.; Surakasi, V.P.; Koul, S.; Ijmulwar, S.; Vivek, A.; Shouche, Y.S.; Kapadnis, B.P.: Electricity generation using chocolate industry wastewater and its treatment in activated sludge based microbial fuel cell and analysis of developed microbial community in the anode chamber. Bioresour. Technol. 100, 5132-5139 (2009). https://doi.org/10.1016/j.biortech.2009.05.041

37. Ketep, S.F.; Bergel, A.; Bertrand, M.; Achouak, W.; Fourest, E.: Sampling location of the inoculum is crucial in designing anodes for microbial fuel cells. Biochem. Eng. J. 73, 12-16 (2013). https:// doi.org/10.1016/j.bej.2013.01.001 